\title{
IDENTIFIKASI PROSES-PROSES GEOMORFOLOGI YANG BERPENGARUH TERHADAP LITIFIKASI ENDAPAN PIROKLASTIK PADA BAGIAN HULU SUNGAI GENDOL PASCA ERUPSI MERAPI TAHUN 2010
}

\author{
Oleh: \\ Dhandhun Wacanodan Efrinda Ari Ayuningtyas \\ Magister Perencanaan Pengelolaan Pesisir dan Daerah Aliran Sungai Fakultas Geografi \\ Universitas Gadjah Mada \\ email: dhancano@gmail.com
}

\begin{abstract}
Abstrak
Letusan Gunungapi Merapi tahun 2010 merupakan letusan yang paling besar selama kurun waktu 100 tahun terakhir. Letusan tersebut mengeluarkan lava dan material piroklastik dengan total kurang lebih 140 juta meter kubik. Material tersebut tersebar pada seluruh wilayah disekitar gunungapi. Lokasi penelitian adalah Sungai Gendol, yaitu salah satu wilayah yang menjadi jalur aliran lava dan material piroklastik letusan Merapi di tahun 2010. Material hasil letusan Merapi akan mengalami proses pengendapan menjadi lapisan batuan volkaniklastik, tetapi dalam prosesnya ada banyak faktor yang mempengaruhi proses litifikasi endapan tersebut. Faktor tersebut adalah proses geomorfologi yang bekerja pada material endapan hasil letusan terutama pada bagian hulu lokasi penelitian. Tujuan dari penelitian ini adalah untuk (a) mengidentifikasi proses-proses geomorfologi yang bekerja pada bagian hulu Sungai Gendol, (b) memetakan proses-proses geomorfologi yang terjadi di hulu Sungai Gendol. Metode yang digunakan dalam penelitian ini adalah metode survei lapangan. Adapun tahapan dalam penelitian ini antara lain meliputi tahap analisis laboratorium dan tahap survei lapangan. Hasil penelitian menunjukkan bahwa Sungai Gendol bagian hulu mengalami proses geomorfologi berupa gerakmassa material endapan dan proses geomorfologi antropogenik.
\end{abstract}

Kata Kunci: Proses geomorfologi, litifikasi, endapan piroklastik

\section{IDENTIFY THE PROCESSES GEOMORPHOLOGY THAT AFFECT THE LITIFIKASIPYROCLASTIC DEPOSITION IN THE UPPER GENDOL RIVER AFTER MERAPI ERUPTION IN 2010}

\begin{abstract}
The Merapi eruption in 2010 was the greatest during the period of the last 100 years. The eruption of pyroclastic material and lava produced a total of approximately 140 million cubic meters. The material was spread on the whole area around the volcano. The study is located in Gendol River (Sungai Gendol), which is one of the areas that became the path of lava flows and pyroclastic material Merapi eruption of 2010. Merapi eruption material will be deposited in the process of becoming rock layers volcaniclastic, but during the process there are a lot of factors that affect the sediment litification process. These factors are geomorphological processes which acts on the eruption material, especially on the upper reaches of the study area. Our research objectives are to (a) identify geomorphological processes working on the upper reaches of The River Gendol, (b) mapping the geomorphological processes that occur in the upper reaches of The River Gendol. This research used a field survey method including laboratory analysis and field survey. The results showed that the upstream part of The River Gendol has
\end{abstract}


Identifikasi Proses-Proses Geomorfologi yang Berpengaruh terhadap Litifikasi Endapan Piroklastik pada Bagian Hulu Sungai Gendol Pasca Erupsi Merapi Tahun 2010

geomorphological processes such as sediment mass movement and anthropogenic geomorphological processes.

Keywords: Process Geomorphology, Litifikasi, pyroclastic deposition

\section{PENDAHULUAN}

Bentanglahan gunungapi merupakan pemandangan yang indah. Keindahan gunungapi tercermin pada aspek kemanfaatanya sebagai sumberdaya alam yang melimpah. Namun demikian gunungapi juga menyimpan bahaya berupa aktivitas letusan, seperti yang terjadi pada letusan Gunungapi Merapi tahun 2010.Gunungapi Merapi merupakan salah gunungapi paling aktifdi Indonesia (Sutikno et al., 2007). Aktivitas Gunungapi Merapi antara lain meliputi letusan, aliran lava, aliran piroklastik, awan panas, debu volkanik, gas beracun, dan aliran lahar (Sulaiman, 2008). Sejarah telah mencatat bahwa letusan paling awal yang terdokumentasi adalah letusan tahun 1006 A.D. (Newhall et al., 2000). Letusan berikutnya tercatat pada tahun 1672 yang mengakibatkan sektar 3000 korban jiwa meninggal karena aliran piroklastik dan aliran lahar (DGWR, 2001). Setelah itu, tercatat bahwa setidaknya telah terjadi 40 kali letusan termasuk 14 kali letusan besar mulai tahun 1821-2006 (DGWR, 2001).

Tipe letusan Merapi 2010 merupakan tipe explosive yang bersifat merusak. Material letusan yang diproduksi oleh letusan Merapi 2010mencapai tigapuluh kali lipat erupsi Merapi tahun 2006. Material tersebut sekarang mengisi lembah-lembah yang menjadi bagian hulu dari sungai-sungai di lereng selatan Gunungapi Merapi (Hadmoko et al., 2011).Salah satu lembah itu adalah Alur Sungai Gendol.Material piroklastik Alur Sungai Gendol berasal dari rangkaian letusan pada tanggal 4-5 November 2010, termasuk didalamnya adalah puncak letusan tanggal 4 November 2010 pukul 17:05 WIB (Surono et al., 2012). Puncak letusan ini menyebabkan runtuhnya kubah lava yang terbentuk selama proses letusan. Aliran piroklastik yang melewati Alur Sungai Gendol menghancurkan permukiman di sekitarnya, dan menyebabkan 367 korban jiwa. Material piroklastik juga menjadi sumber terjadinya bahaya sekunder berupa banjir lahar. Bronto et al. (2011) menyebutkan sekitar 34 juta $\mathrm{m}^{3}$ material piroklastik pada Alur Sungai Gendol berpotensi menjadi aliran lahar.

Endapan material piroklastik tersebut akan mengalami proses pengendapan menjadi lapisan endapan batuan volkaniklastik gunungapi. Lapisan endapan tesebut memiliki banyak kegunaan, salah satunya adalah sebagai komponen pembentuk lapisan akuifer air tanah pada daerah tangkapan air hujan. Namun, ada kalanya proses pengedapan yang terjadi mengalami proses-proses eksogen yang dapat berpengaruh terhadap proses litifikasi material tersebut. Proses-proses eksogen secara alami termasuk dalam proses-proses geomorfologi, yaitu proses-proses alam yang membentuk suatu bentukan khas yang disebut dengan bentuklahan. Selain proses alami, ada kalanya pengaruh aktivitas manusia juga menjadi salah satu faktor yang mempengaruhi proses litifikasi endapan material letusan Merapi.

Identifikasi proses-proses alam maupun buatan yang berpengaruh terhadap proses litifikasi endapan piroklastik merupakan hal yang penting dilakukan sebagai langkah awal dalam identifikasi masalah lingkungan terkait dengan pemanfaatan 
sumberdaya dan pengelolaan bencana sedimen. Lokasi penelitian ini dilakukan pada bagian hulu Sungai Gendol. Pemilihan lokasi penelitian didasari oleh kondisi relief dan topografi yang sesuai untuk kajian proses geomorfologi. Selain itu lokasi penelitian juga merupakan pintu gerbang aliran material piroklastik tahun 2010 (Gambar 1). Bagian hulu merupakan bagian penting untuk diteliti karena material endapan piroklastiknya tebal dan belum banyak tersentuh oleh kegiatan manusia seperti halnya kegiatan tambang. Peta lokasi penelitian ditunjukkan pada Gambar 1.

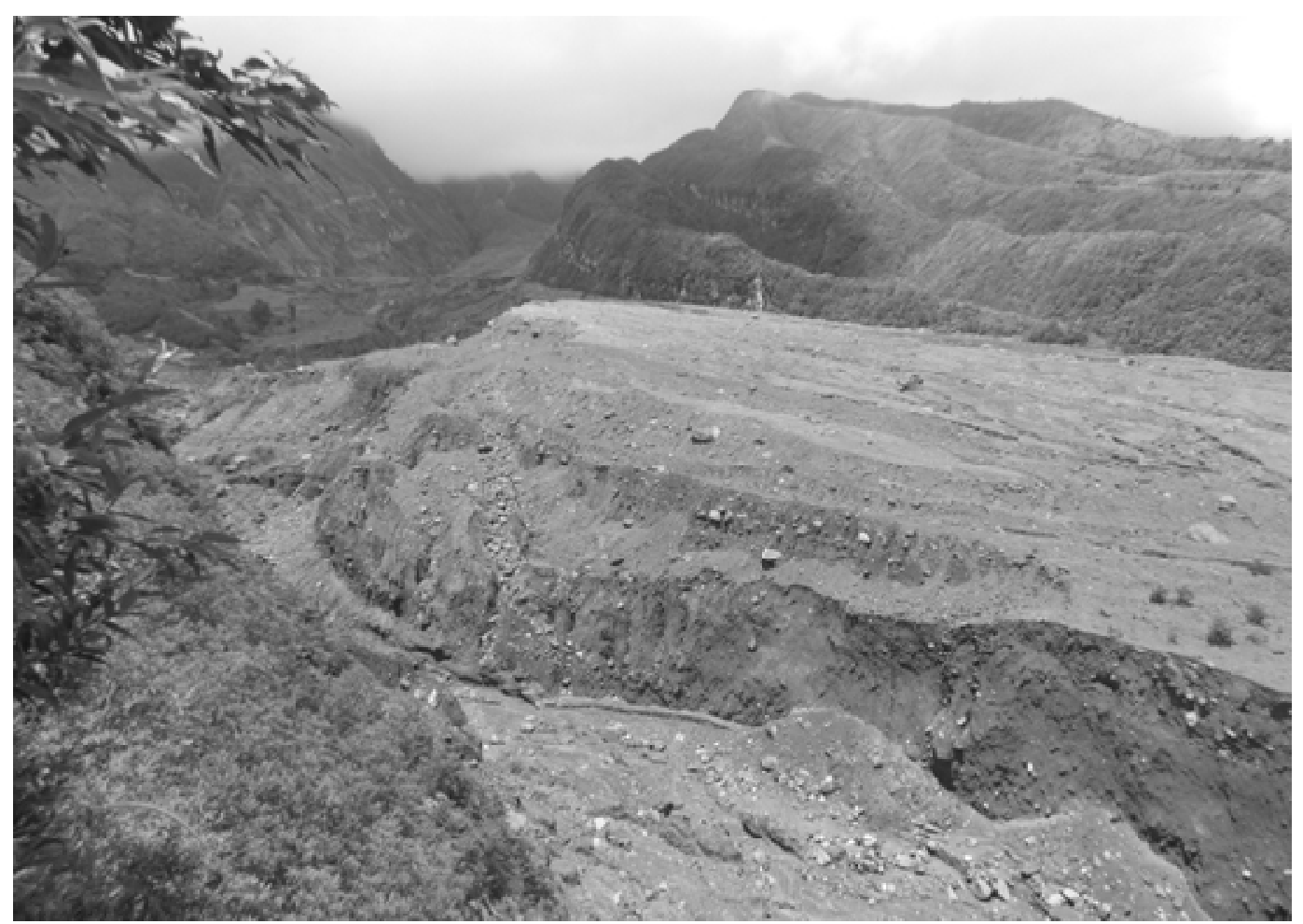

Gambar 1. Kondisi bagian hulu Sungai Gendol.

Gambar 1 di atas menunjukkan bahwa endapan aliran piroklastik letusan Merapi 2010 keluar melalui celah sempit yang merupakan patahan normal dengan arah patahan baratdaya-timurlaut. Endapan material piroklastik ini mengisi hampir seluruh lembah yang ada dibagian hulu dengan ketebalan mencapai lebih dari 65 meter.

Adapun tujuan dari penelitian ini antara lain: (1) mengidentifikasi proses-proses geomorfologi yang bekerja pada bagian hulu Sungai Gendol, (2) memetakan prosesproses geomorfologi yang terjadi di hulu Sungai Gendol 
Identifikasi Proses-Proses Geomorfologi yang Berpengaruh terhadap Litifikasi Endapan Piroklastik pada Bagian Hulu Sungai Gendol Pasca Erupsi Merapi Tahun 2010

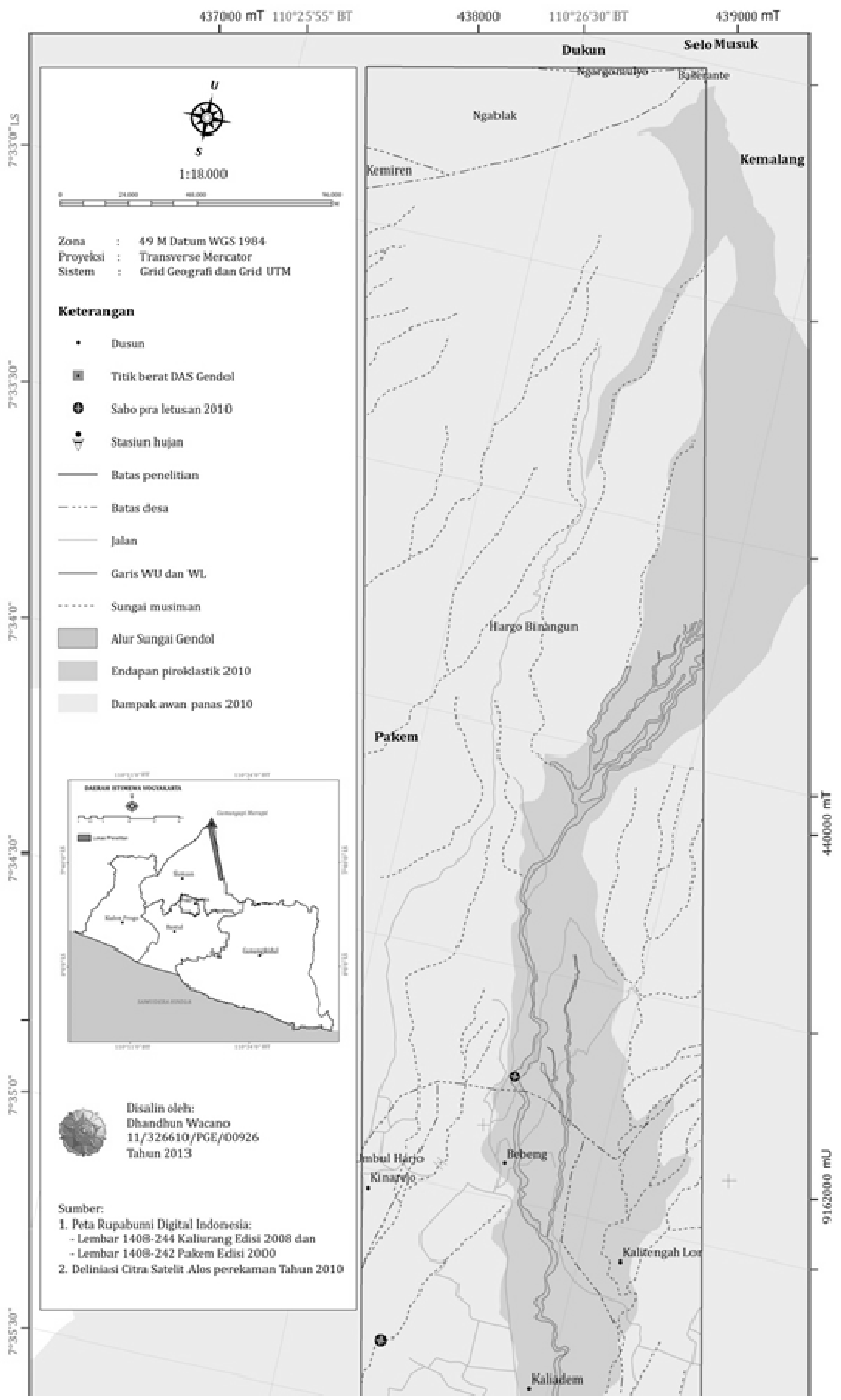

Gambar 2. Peta Lokasi penelitian 


\section{Metode}

Metode dalam penelitian ini adalah metode survei lapangan. Namun dalam pelaksanaanya, penelitian ini dilakukan melalui beberapa tahapan, tahapan itu meliputi tahap analisis laboratorium dan tahap survei lapangan. Analisis proses geomorfologi lokasi penelitian dilakukan dengan interpretasi citra satelit dan survei lapangan. Citra yang digunakan untuk interpretasi proses geomorfologi adalah citra Geo-Eye tahun perekaman 2011. Citra Geo-Eye merupakan citra satelit yang memiliki resolusi spasial tinggi. Citra satelit ini mempermudah kita untuk mengenali objek dengan jelas, sehingga kenampakan proses geomorfologi secara detil dapat terlihat dengan baik. Khususnya untuk proses geomorfologi dalam lingkup mikro.

Identifikasi proses geomorfologi juga dilakukan dengan survei langsung di lapangan. Pada survei lapangan, kegiatan yang dilakukan antara lain pengamatan, pengukuran, dan pengambilan sampel material. Terkait dengan interpretasi proses geomorfologi menggunakan citra satelit, kegiatan survei lapangan berfungsi sebagai bahan validasi hasil interpretasi yang sifat subjektifitasnya masih tinggi. Hasil kegiatan interpretasi dan survei lapangan berhasil mengindentifikasi proses-proses geomorfologi yang terjadi pada lokasi penelitian. Mengingat dinamika alur sungai Gendol yang sangat tinggi, maka waktu penelitian ini dibatasi pada periode bulan Januari-Februari tahun 2013.

\section{Hasil dan Pembahasan}

Survei lapangan merupakan sebuah metode yang banyak memakan biaya, waktu, dan tenaga. Namun, survei lapangan juga memiliki banyak keuntungan, salah satunya adalah pemahaman langsung di lapangan tentang proses alam yang terjadi secara faktual. Bahkan, dengan majunya teknologi seperti saat ini memungkinkan kita untuk melakukan inovasi dengan teknik survei cepat terintegrasi terhadap fenomena alam seperti proses geomorfologi berupa gerak massa batuan (Wacano, 2013). Hasil kegiatan survei dan interpretasi citra satelit pada lokasi penelitian barhasil mengidentifikasi prosesproses geomorfologi yang saat ini sedang terjadi. Proses-proses geomorfologi yang teridentifikasi tersebut antara lain: erosi, longsor tipe runtuhan material endapan, runtuhan tebing sungai, aliran lahar, dan kegiatan tambang.

\section{Proses Geomorfologi Alami}

Proses geomorfologi alami merupakan proses geomorfologi karena pengaruh tenaga alami. Tenaga alami tersebut meliputi gaya gravitasi, tenaga kinetik hujan, tenaga pelarut air permukaan, dan tenaga getaran. Lokasi penelitian memiliki kondisi relief bergunung dengan kelerengan yang miring hingga terjal. Kondisi relief ini sangat berpengaruh terhadap proses yang bekerja pada endapan material piroklastik dan terlihat pada proses geomorfologi yang dijumpai banyak terjadi di bagian permukaan endapan piroklastik yaitu erosi. Erosi yang terjadi dipermukaan endapan piroklastik bervariasi jenisnya. Jenis-jenis erosi yang ditemui antara lain merupakan urutan proses erosi mulai dari erosi lembar, erosi percik, erosi parit, hingga erosi alur. Gambar 3a. merupakan salah satu contoh bentuklahan sisa hasil erosi berupa alur-alur yang memanjang searah dengan arah aliran air. 

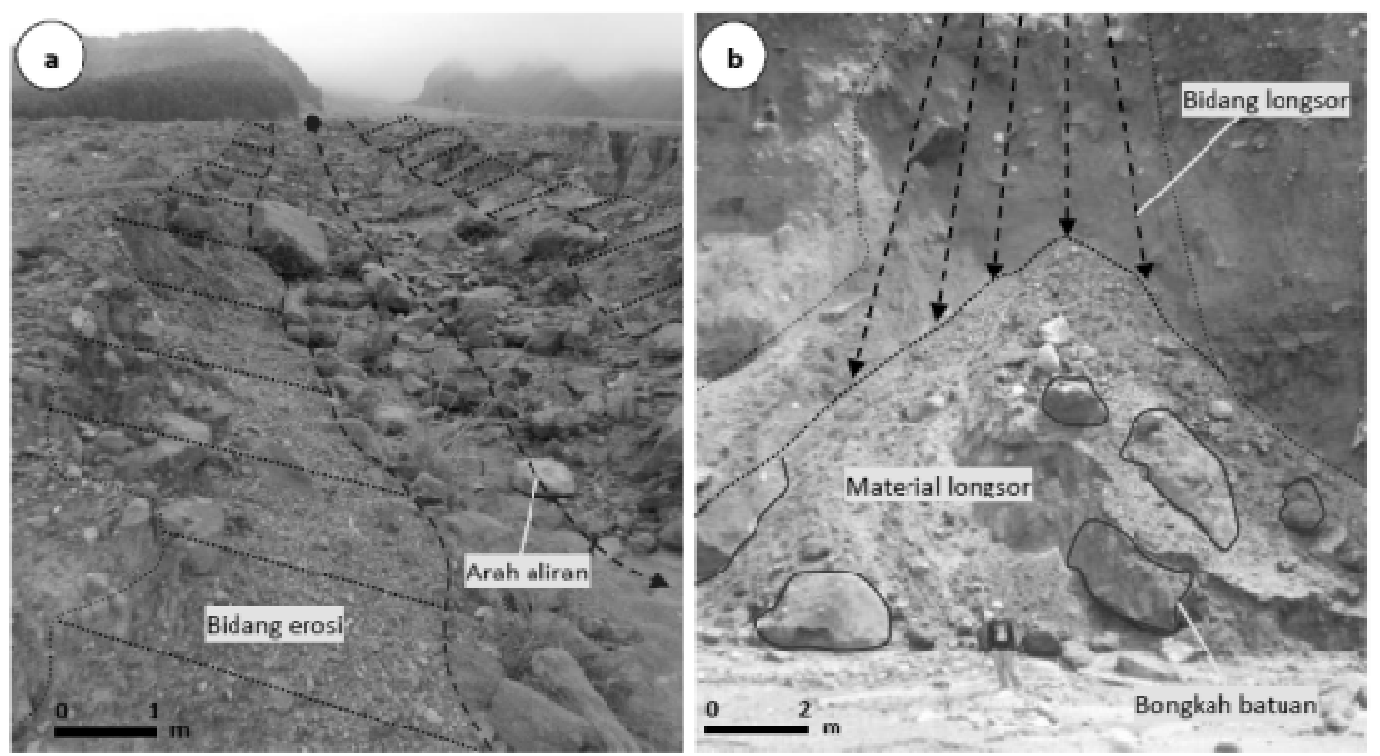

Gambar 3. Proses geomorfologi (a) erosi alur (b) runtuhan endapan piroklastik

Proses erosi diawali dengan lepasnya partikel-partikel material endapan gunungapi Merapi oleh tenaga hujan. Hujan memiliki tenaga kinetik yang dapat melepaskan ikatan kohesi antar partikel-partikel pada material endapan. Partikel tanah yang bersifat lepaslepas kemudian terangkut oleh limpasan air permukaan. Proses pengangkutan partikelpartikel endapan material letussan pada akhirnya akan membentuk berbagai bentuk dan tipe erosi, antara lain erosi percik, erosi lembar, erosi parit, dan erosi alur. Hasil proses erosi lanjut akan menghasilkan lembah-lembah baranco dan alur-alur sungai.

Proses geomorfologi berupa gerakmassa batuan tipe runtuhan endapan piroklastik juga ditemui pada lokasi penelitian. Gerak massa batuan atau sering disebut dengan longsor merupakan proses geomorfologi yang juga terjadi pada lokasi penelitian. Longsor sangat dipengaruhi oleh faktor utama berupa gaya gravitasi. Longsor akan mengalami percepatan akibat faktor pemicu berupa air hujan, getaran, dan tekanan. Longsor pada lokasi penelitian banyak terjadi di bagian hulu terutama terjadi pada tebing-tebing alur sungai Gendol. Longsor yang terjadi merupakan gerak massa tipe runtuhan. Runtuhan material dapat terjadi karena endapan letusan yang bersifat lepas-lepas berada pada lereng yang sangat terjal, sehingga gaya gravitasi akan membuat material endapan tersebut runtuh menuruni tebing. Runtuhan material biasanya terdiri dari besar butir yang acak. Gambar 3b. Menunjukkan longsoran tipe runtuhan dengan komposisi besar butir yang acak.

Endapan piroklastik jika terpicu oleh hujan akan menjadi gerak massa batuan tipe debris flow atau sering kita kenal sebagai banjir lahar.Lahar (debris flow) merupakan aliran gerak massa runtuhan karena tenaga gravitasi yang tersusun atas campuran material berukuran lempung hingga batu-batu besar, mengalir melalui alur sungai (USGS, 2008). Schwarzkopf (2005) menjelaskan bahwa lahar memiliki densitas dan viskositas konsentrasi partikel yang sangat tinggi. Deposit lahar diendapkan secara cepat dalam arus turbulen di sepanjang lereng gunungapi atau lembah-lembah sungai (Aisyah et al., 2012). Aliran lahar yang terjadi pada lokasi penelitian merupakan aliran lahar yang berskala kecil. Artinya 
lahar pada bagian hulu Sungai Gendol merupakan awal mula lahirnya proses aliran lahar. Aliran lahar ini mengalir di sepanjang alur Sungai Gendol dan tepat berada di atas endapan piroklastik yang mengisi bagian dalam alur Sungai Gendol. Hal ini dapat diidentifikasi dari tebalnya endapan lahar yang ada pada lokasi penelitian yakni tidak lebih dari 1 meter. Lebih lanjut aliran lahar juga dapat menyebabkan runtuhan tebing lembah alur sungai. Hal ini dapat terjadi karena interaksi antar fragmen batuan ketika terjadi aliran turbulensi lahar menyebabkan getaran yang dapat mengganggu stabilitas material pada tebing alur.

Material endapan letusan dapat mengalami proses perubahan posisi dan bentuk secara khusus. Perubahan posisi dan bentuk ini termasuk dalam proses deposisional. Proses deposisional dipengaruhi oleh kombinasi beberapa faktor penyebab, yaitu gaya gravitasi, aliran air, hembusan angin, dan morfometri saluran sumber material tersebut berasal. Gaya gravitasi secara langsung akan membuat butir-butir material piroklastik jatuh menuruni lereng. Butir-butir tersebut kemudian tersusun kembali secara vertikal di atas permukaan lereng. Pada awalnya butir-butir tersebut tersusun secara melebar pada bagian dasar, tetapi berangsur-angsur akan menyempit ketika mendekati bagian atas saluran, sehingga akan terbentuk bentukan seperti kipas pada permukaan lereng atau tebing (Gambar 4).

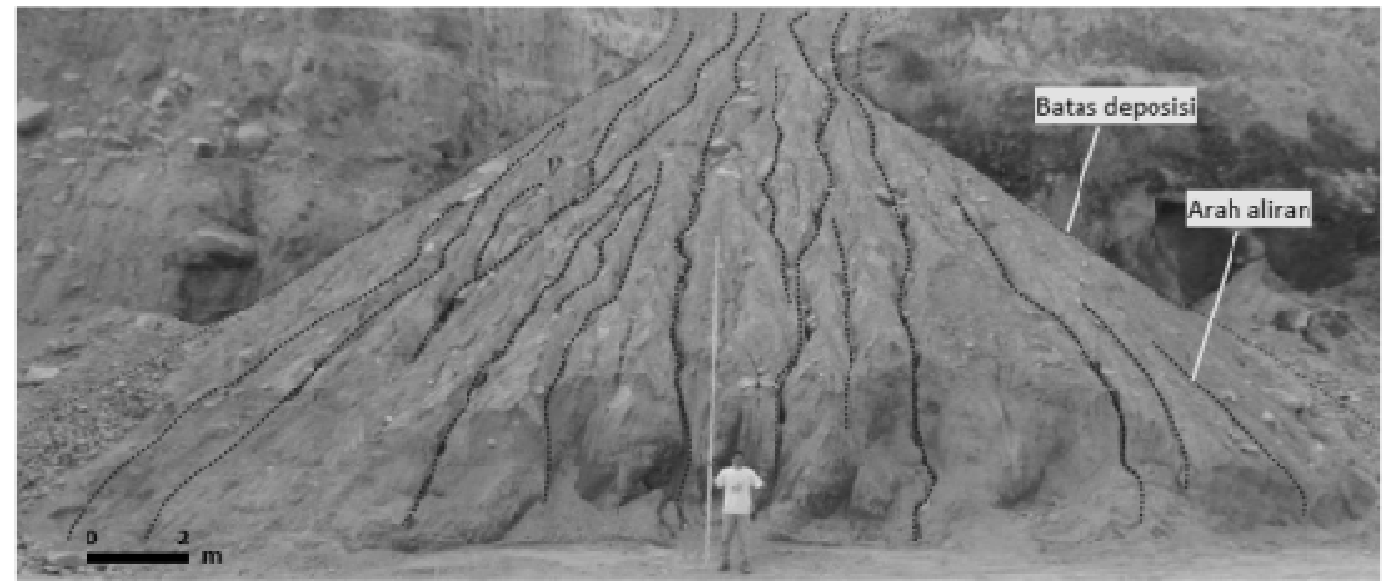

Gambar 4. Proses deposisi material endapan piroklastik menjadi kipas piroklastik

Gambar 4. merupakan bentukan hasil proses deposisional berupa kipas piroklastik. Pembentukan kipas piroklastik sangat dikontrol oleh morfometri saluran tempat dimana material bergerak melewati lereng. Endapan seperti kipas ini disebabkan oleh bentuk saluran yang cekung pada bagian atas dan berangsur-angsur melebar seperti kerucut dibagian bawahnya. Faktor aliran air dan hembusan angin juga sangat berpengaruh terhadap proses deposisional material yang terjadi. Alur-alur kecil pada kipas piroklastik menunjukkan adanya kontribusi aliran air pada proses deposisional kipas piroklastik. Proses deposisional yang lain dapat juga dijumpai pada bentukan deposisional lainya berupa kipas lahar dan kipas aluvial, meskipun hanya pada skala minor.

\section{Proses Geomorfologi Antropogenik}

Aliran piroklastik (pyroclastic flow) adalah gerak massa fragmen-fragmen batuan serta gas volkanik yang bergerak sangat cepat karena pengaruh gaya gravitasi meluncur 
dari kawah gunungapi melalui lembah-lembah volkan (Thouret, et al., 2000; Voight, et al., 2000 dan DGWR, 2001). Endapan material letusan Merapi dapat dikategorikan berasal dari endapan pyroclastic flow dan pyrocalstic fall (Andreastuti et al., 2000). Endapan aliran piroklastik ini dapat diamati dari distribusi sebaran granulometri material (Lavigne et al., 2002).

Endapan aliran piroklastik banyak dimanfaatkan untuk kegiatan tambang. Tambang yang dilakukan saat ini bertujuan untuk memperbesar kapasitas alur Sungai Gendol ketika nanti terjadi letusan berikutnya, sehingga alur Sungai Gendol dapat menampung aliran piroklastik pada letusan selanjutnya. Namun, tidak semua daerah tersebut boleh dan layak untuk kegiatan tambang. Selain kualitas material tambang sendiri yang berbeda-beda sesuai dengan tipe dan sifat endapan piroklastiknya, kegiatan tambang yang dilakukan dilokasi-lokasi yang tidak boleh dilakukan penambangan akan merusak lingkungan alur sungai itu sendiri. Salah satu lokasi yang tidak boleh dilakukan penambangan tersebut adalah lokasi hulu Sungai Gendol.

Proses geomorfologi karena faktor antropogenik ini sudah berlangsung di lokasi penelitian. Selama proses penambangan yang telah dilakukan ternyata banyak sekali perubahan yang terjadi pada daerah penelitian. Perubahan itu dominan terjadi pada bagian dalam alur Sungai Gendol dimana pasir yang dahulu memenuhi alur sungai sekarang telah mengalami pengurangan yang signifikan karena proses penambangan. Penambangan ini umumnya ditinjau sebagi normalisasi lembah sungai untuk aliran permukaan dan memperbaiki alur agar dapat dilewati material yang serupa jika terjadi erupsi kembali. Masalah yang muncul adalah tidak semua material piroklastik mulai dari ukuran bongkah (boulder) hingga pasir dapat ditambang. Sebagian besar batu-batu besar dan kerakal masih menumpuk dan tertinggal di dalam alur sungai dan dikanan kiri sungai (Gambar 5a-b). dengan demikian, penambangan untuk tujuan normalisasi alur lembah Sungai Gendol agar mengurangi risiko bahaya sekunder menjadi masalah lingkungan yang harus diperhatikan.

Lokasi hulu Sungai Gendol merupakan tempat dimana proses alami harus dibiarkan apa adanya. Hal ini sangat terkait dengan proses bentanglahan yang secara alami akan berproses menuju kesetimbangan. Jika aktivitas manusia turut mempengaruhi dan mengganggu proses tersebut, maka risiko lingkungan seperti bencana banjir lahar yang dapat mentransport fragmen batuan berukuran lebih dari 4 meter sampai pada lokasi yang seharusnya material tersebut tidak dapat mencapainya.

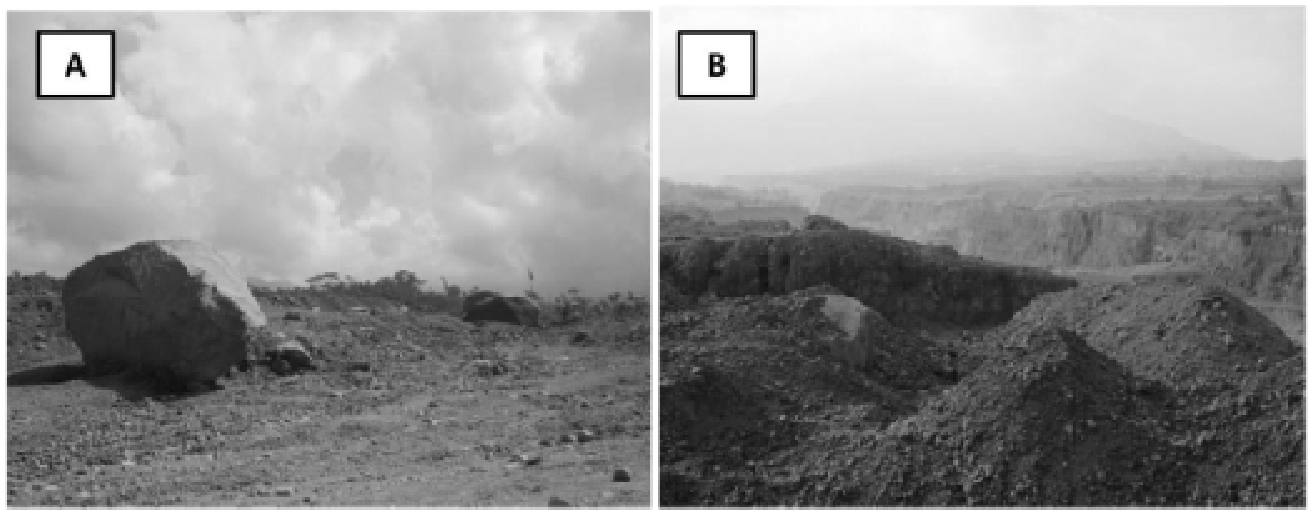

Gambar 5. Sisa penambangan (a) boulder diameter 2-8 m (b) kerakal diameter 2-5 cm 


\section{Pemetaan Proses Geomorfologi}

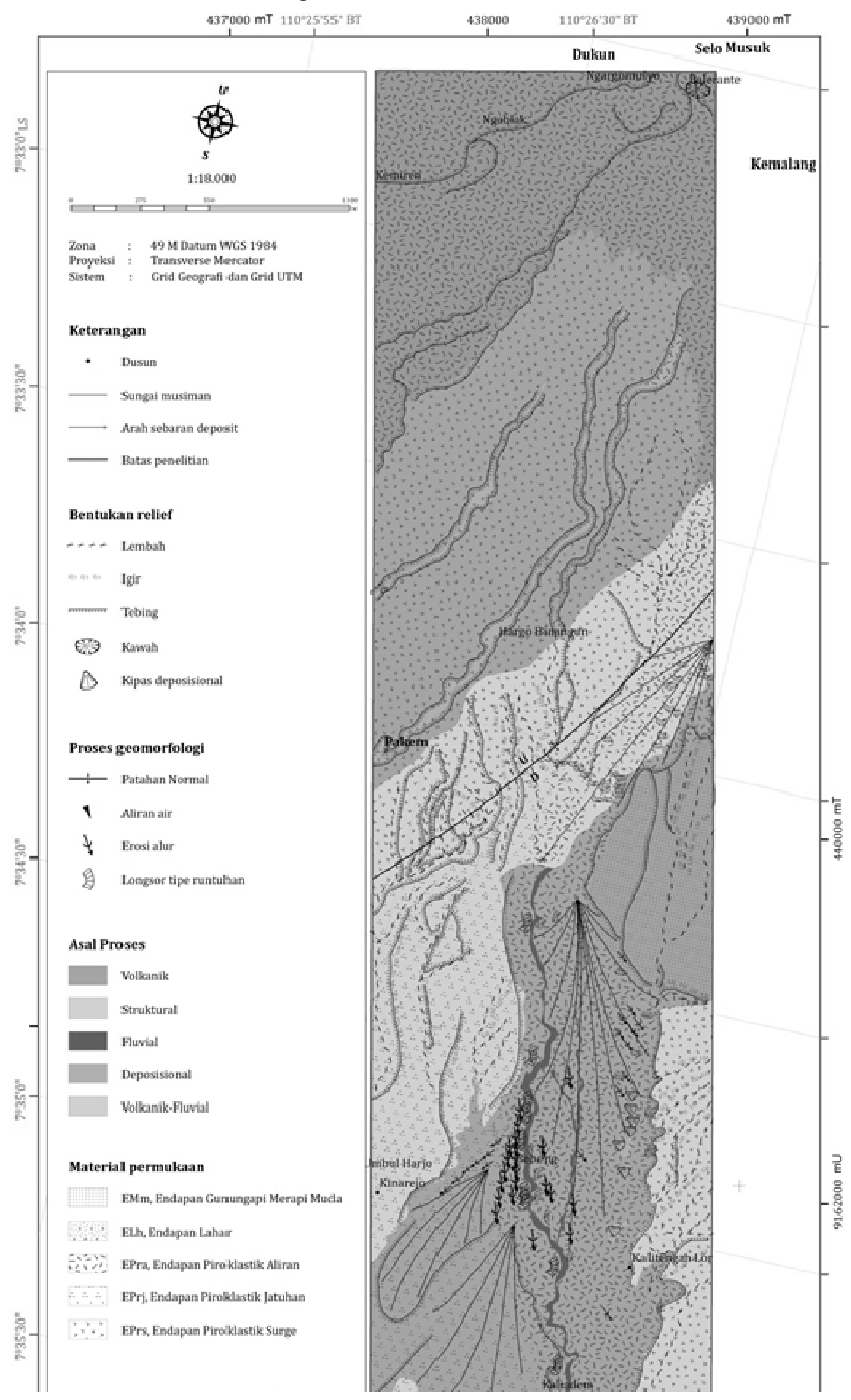

Gambar 6. Peta proses-proses geomorfologi lokasi penelitian 
Pemetaan proses geomorfologi dilakukan untuk mempermudah dalam melihat sebaran secara keruangan dari proses-proses geomorfologi yang terjadi pada lokasi penelitian. Peta proses-proses geomorfologi tersebut ditunjukkan pada Gambar 6. Pada peta tersebut dapat diketahui bahwa proses geomorfologi di daerah penelitian terjadi pada material endapan piroklastik aliran. Proses geomorfologi baik alami maupun antropogenik terjadi di dalam alur Sungai Gendol. Pada identifikasi lapangan ditemukan kipas deposisional material piroklastik berada pada tebing bagian barat lokasi penelitian. Gerakmassa tipe runtuhan terjadi pada hampir seluruh tebing alur lokasi penelitian, sedangkan erosi tipe alur sebagian besar terjadi di bagian timur lokasi penelitian.

Proses-proses geomorfologi alami tersebut berlangsung secara terus menerus dengan laju proses relatif lambat, sehingga proses kompaksi endapan piroklastik dapat terjadi meskipun ada proses eksogen yang bekerja pada endapan tersebut. Hal ini nampak pada struktur masif dan kompak permukaan endapan piroklastik pada lokasi penelitian. Struktur masif tersebut terbentuk dari proses sementasi debu volkanis yang banyak mengandung silikat. Kandungan silikat tersebut justru akan mengeras ketika kontak dengan udara dan air hujan. Proses kompaksi akan lebih cepat terjadi ketika material piroklastik tersebut masih memiliki suhu yang tinggi. Namun yang menjadi persoalan adalah kegiatan penambangan oleh masyarakat yang saat ini telah mencapai lokasi disekitar Kaliadem dan Bebeng. Kegiatan tambang ini akan membuka lapisan endapan piroklastik yang sebenarnya sedang dalam proses kompaksi endapan. terbukanya lapisan endapan piroklastik tersebut semakin memperbesar risiko bencana sekunder seperti aliran lahar dan runtuhan material endapan.

\section{Kesimpulan}

Hasil penelitian ini menyimpulkan bahwa pada bagian hulu Sungai Gendol saat ini telah terjadi proses geomorfologi alami dan proses geomorfologi antropogenik. Proses geomorfologi alami berupa gerak massa batuan tipe runtuhan material dan aliran lahar, sedangkan proses geomorfologi antropogenik berupa aktivitas penambangan yang membentuk lubang-lubang bekas penambangan. Proses geomorfologi alami seperti longsor tebing endapan piroklastik dan aliran lahar merupakan proses alam yang perlu menjadi perhatian dalam hal pengurangan risiko bencana sedimen. proses geomorfologi buatan karena aktivitas penambangan perlu menjadi perhatian khusus untuk evaluasi kegiatan penambangan yang selama ini telah dilakukan.

\section{Daftar Pustaka}

Aisyah, N., Purnamawati, D.I. 2012. Tinjauan Dampak Banjir Lahar Kali Putih, Kabupaten Magelang Pasca Erupsi Merapi 2010. Jurnal Teknologi Technoscientia, Vol. 5 No. 1: $19-30$.

Andreastuti, S.D., Alloway, B.V., Smith, I.E.M. 2000. A detailed tephrostratigraphic framework at Merapi Volcano Central Java Indonesia: implications for eruption predictions and hazard assessment. Journal of Volcanology and Geothermal Research, Vol. 100: 51-67. 
Bronto, S., Sayudi, D. S., Muzani, M., Putra, R. 2011. Potential Hazard of Merapi in The Near Future. International Workshop Lesson Learned from the 2010 Merapi Eruption, November 01-02 2011. Yogyakarta.

Directorate General of Water Resources (DGWR). 2001. Review Master Plan Study on Mt Merapi. Supporting Report [B] Volcanic Disaster Mitigation Plan. Ministry of Settlement and Regional Infrastructure, Republik Indonesia.

Hadmoko, D.S., Marfai, M.A., Widiyanto, Permatasari, A.L., Wacano, D. 2011. Pemodelan Mikrozonasi Risiko Bahaya Lahar Akibat Erupsi Merapi 2010 di Wilayah Perkotaan: Kasus Aliran Sungai Code. Laporan Penelitian. Pascasarjana Universitas Gadjah Mada.

Lavigne, F., Thouret, J.C. 2002. Sediment transportation and deposition by rain-triggered lahars at Merapi Volcano Central Java Indonesia. Geomorphology, Vol. 49: 4569.

Newhall et al., 2000 Newhall, C.G., Bronto, S., Alloway, B., Banks, N.G., Bahar, I., del Marmol, M.A., Hadisantono, R.D., Holcomb, R.T., Mc Geehin, J., Miksic, J.N., Rubina, M., Sayudi, S.D., Sukhyar, R., Andreastuti, S., Tilling, R.I., Torley, R., Trimble, D., Wirakusumah, A.D. 2000. 10.000 Years of explosive eruptions of Merapi Volcano, Central Java: archaeological and modern implications. Journal of Volcanology and Geothermal Research, Vol. 100: 9-50.

Schwarzkopf, L.M., Schmincke, H.U., Cronin, S.J. 2005. A conceptual model for block-andash flow basal avalanche transport and deposition, based on deposit architecture of 1998 and 1994 Merapi flows. Journal of Volcanology and Geothermal Research, Vol. 139: 117-134.

Sulaiman, M. 2008. Classification and Identification of Grain Size Distribution: Study on Porosity of Sediment Mixtures and a Bed-porosity Variation Model. Ph.D Thesis. Disaster Prevention Research Institute of Kyoto University: Japan 59-84.

Surono, Jousset, P., Pallister, J., Boichu, M., Buongiorno, M.F., Budisantoso, A., Costa, F., Andreastuti, S., Prata, F., Schneider, D., Clarisse, L., Humaida, H., Sumarti, S., Bignami, C., Griswold, J., Carn, S., Oppenheimer, C., Lavigne, F. 2012. The 2010 explosive eruption of Java's Merapi volcano-A '100-year' event. Journal of Volcanology and Geothermal Research Vol. 241-242: 121-135.

Sutikno, Santoso, W.L., Widiyanto, Kurniawan, A., Purwanto, T.H. 2007. Kerajaan Merapi Merapi Kingdom. Badan Penerbit Fakultas Geografi Universitas Gadjah Mada. Yogyakarta.

Thouret, J.C, Lavigne, F., Kelfoun, K., and Bronto, S. 2000. Toward a revised hazard assessment at Merapi volcano, Central Java. Journal Volcanology. Geotherm. Res., Vol. 100: 479-502.

USGS. 2008. The Landslide Handbook-A Guide to Understanding Landslides. Reston: Virginia

Voight, B., Constantine, E.K., Siswowidjoyo, S., and Torley, R. 2000. Historical eruptions of Merapi Volcano Central Java Indonesia 1768-1998. J. Volcanol. Geotherm. Res., Vol.100: 69-138 
Identifikasi Proses-Proses Geomorfologi yang Berpengaruh terhadap Litifikasi Endapan Piroklastik pada Bagian Hulu Sungai Gendol Pasca Erupsi Merapi Tahun 2010

Wacano, D., Hadmoko, D.S., Susmayadi, I.M., Nurohman, S., Mujianto, B.A., Nugroho, A.S. 2013. Identifikasi Tipologi Longsor Untuk Analisis Mitigasi Bencana Studi Kasus: Dusun Sidorejo, Desa Tieng, Kejajar Wonosobo. Seri Bunga Rampai "Zamrud Khatulistiwa". ISBN: 978-602-7797-25-3. Kanisius, Yogyakarta-Indonesia 